\title{
Taking a Step Back? Expatriation Consequences on Women in Dual-Career Couples in the Gulf
}

\author{
Maranda Ridgway (D)
}

Citation: Ridgway, M. Taking a Step Back? Expatriation Consequences on Women in Dual-Career Couples in the Gulf. Merits 2021, 1, 47-60.

https://doi.org/10.3390/merits1010006

Received: 21 May 2021

Accepted: 15 June 2021

Published: 21 June 2021

Publisher's Note: MDPI stays neutral with regard to jurisdictional claims in published maps and institutional affiliations.

Copyright: (C) 2021 by the author. Licensee MDPI, Basel, Switzerland. This article is an open access article distributed under the terms and conditions of the Creative Commons Attribution (CC BY) license (https:/ / creativecommons.org/licenses/by/ $4.0 /)$.
Nottingham Business School, Nottingham Trent University, Nottingham NG1 4FQ, UK; maranda.ridgway@ntu.ac.uk

\begin{abstract}
This article develops our understanding of how host country contextual features affect the career coordination strategies of dual-career couples (DCCs) from the perspective of expatriate women. The lived experiences of nine women expatriates in the Gulf Cooperation Council (GCC) were explored through in-depth interviews. The findings challenge our understanding of the coordinated career strategies of DCCs by suggesting that sociocultural features of the host country context can hamper egalitarian career strategies such that they become hierarchical and subsequently negatively impact women expatriates' career capital. Not only are women's careers hampered while in the GCC, but the contextual setting has a long-term adverse effect on women's career capital. The main results from this study suggest that sociocultural features of the host country setting, such as the inability to access professional networks due to gendered segregation, prevent women's careers from being prioritised and force a 'tipping point', creating a lag in women's careers and negatively impacting their career capital.
\end{abstract}

Keywords: career capital; career coordination strategy; dual-career couples; expatriates; gender; global mobility; Gulf Cooperation Council

\section{Introduction}

As organisations continue to expand into the global marketplace, there is an increasing need for globally mobile professionals [1]. In the field of global mobility, women have traditionally taken the role of 'trailing spouse', following their husbands' international careers. In recent years, there has been an increase in the number of dual-career couples (DCCs) and, subsequently, female expatriate workers [1], yet overall, women's participation in the labour market remains disproportionately low [2,3]. Progress has been made in the development of our understanding of how gender and family relations affect international career opportunities. However, Gripenberg, Niemistö and Alapeteri [4] report that while equality between partners is increasing, the equality of employment offers, for example, salary levels, between men and women is decreasing; thus, international assignments appear to reinforce traditional gender roles [5].

Research has shown that DCCs adopt coordinated strategies to manage their careers [5]. However, it is unclear how contextual features of the host country may affect these coordinated career strategies. For example, in a patriarchal society, this may manifest in the assumption that it remains a woman's responsibility to arrange and provide childcare, despite having her career. This article problematises how the careers of expatriate women in DCCs are affected in male-dominated environments, such as the Gulf Cooperation Council (GCC), which is also a region notoriously reliant on foreign workers. The GCC Statistical Centre [6] reports that in 2015 the labour force in the GCC comprised $64 \%$ foreign workers, of which only $9 \%$ were women. The GCC is an under-researched region [7] and thus presents an interesting context for consideration, as women might face challenges in continuing their careers that do not exist in their home countries, thus hampering their coordinated career strategies. Furthermore, as Kemp and Rickett [8] 
(p. 344) argue, 'foreign women are a potential and emergent, yet under-investigated, subset of the global labour market'.

This study drew upon qualitative data gathered through in-depth interviews with female expatriates in DCCs to explore the consequences of expatriation in the GCC on their careers. The aim of this research was to further our understanding of how contextual features affect expatriate women in DCCs. To achieve this aim, the lived experiences of women expatriates were explored. Specifically, the following research question was considered:

RQ: How is the career capital of expatriate women affected by working in the Middle East as part of a DCC?

It is important to continue developing our understanding in this field because different sociocultural environments may hinder expatriates' decisions to pursue international work opportunities if coordinated career strategies cannot be achieved. Furthermore, although women's participation in expatriation has increased, they are still under-represented [4]. Thus, increasing our understanding of the implications for women in DCCs may provide insight into how this imbalance can be addressed.

This article is organised into five sections. Following this introduction, the first section discusses the career strategies of DCCs and examines expatriate women's career capital in a Middle Eastern context. The second section details the research protocol that was used for this study. The findings form the third section and are organised around themes of career sacrifice, career lagging, unforeseen barriers and prioritising women's careers. The final sections present a discussion and conclusions in which directions for future research are identified.

\section{Literature Review}

\subsection{Dual-Career Couples and Their Career Strategies}

While the nature of expatriation and typologies of expatriates remains a point of debate [9] and the demarcation continues to evolve [10], for this article, the term 'expatriate' is used to refer collectively to self-initiated expatriates (SIEs) and expatriates who have been sent overseas by their existing employers, namely 'assigned expatriates' (AEs).

Traditionally, the role of women in global mobility has been limited to that of trailing spouses, following their husband's careers around the world on different international assignments. One cause may be that 'policymakers tend to build in a restriction that dependents cannot claim a stronger position than the principal migrant they are tied to' [11] (p. 148). Research has established that in a domestic setting, in DCCs, traditional roles of male breadwinner and female homemaker remain, despite both couples pursuing individual careers [12]. It has been argued that it is a trailing spouse's lack of career salience, and thus willingness to follow her partner overseas, which is the strongest predictor of an employee's willingness to relocate [13]. As alternative forms of expatriation have become increasingly popular, such as SIEs [14], flexpatriates [15] and expatriate entrepreneurs [16], there has been a rise in DCCs which suggests that trailing spouses are pursuing their careers in an international setting [1]. As the number of DCCs has risen, so too has the prominence of a coordinated approach to accommodate both partners' careers [3], insinuating a reversal of traditional roles as both partners pursue international careers concurrently. In this regard, DCCs can be defined as a couple who are both 'masters of their own careers' [17] (p. 49) and 'psychologically committed to their professions' [18] (p. 178).

In their seminal study, Känsälä et al. [5] examined the different career coordination strategies used by DCCs which they categorise as hierarchical strategy, egalitarian strategy and loose coordination strategy. The hierarchical strategy reflects one partner following the other's career. While they report some cases of husbands following their wives, more frequently wives followed their husbands' careers; thus, the husband's career is prioritised in the hierarchy. Slobodin [19] suggests that women feel obliged to cease their careers to spend more time with their family as compensation for their spouse's extended working hours. Although women may find international exposure enriching, they may concurrently experience personal conflict [20]. The egalitarian strategy [5] indicates that neither partner's 
career is prioritised over the other. In another study [21] the 'career kaleidoscope' metaphor has been used to depict how partners take turns in whose career 'leads'. Similarly, repatriation has been used as a form of negotiation to enable the 'lagging' partner to reinvest in their career [22]. International experience is increasingly becoming a prerequisite for senior-level progression [23], and although there is an increase in DCCs, women are still under-represented within the expatriate workforce [4] which could hinder their long-term career progression. Känsälä et al.'s [5] final category, loose coordination strategy, describes a scenario where partners' career decisions are made independently which may result in only one partner relocating internationally; thus, their careers take priority over family life.

In DCC scenarios, women continue to be expected to act as the primary caregiver for children while maintaining their careers [20,24], often curtailing senior-level progression to allow a balance between work and family responsibilities [25]. As Känsälä et al. [5] (p. 2206) indicate, this often results in a 'double burden for female expatriates'.

\subsection{Expatriate Women's Career Capital in a Middle Eastern Contextual Setting}

Contextually, this research was conducted with expatriates who are currently, or have recently, worked in GCC countries, namely Bahrain, Kuwait, Oman, Qatar, Saudi Arabia and the United Arab Emirates (UAE). The GCC is an interesting context as it is the world's most expatriate-reliant region but remains comparatively under-researched $[7,26]$. The social hierarchy in the GCC manifests as a male-dominant socio-political context. Such a context is significant as it provides a framework for the way that social systems are constructed [27] and the level of constraint in terms of how women's experiences within work and society are shaped [28].

The GCC is a male-dominated patriarchal environment, indicating a social setting in which men are favoured over women [29], which adds complexity to the way that women's expatriation experiences play out. Despite the increase in women's participation in the labour market [30], women expatriates encounter barriers that may not be present in their home countries [31]. In practical terms, women face visa restrictions (except for a few professions) which prevent them from sponsoring their husbands [32,33] and thus not taking their 'turn' as the leading partner in a DCC. Thus, embedded institutional and sociocultural practices result in women experiencing a detriment in employment settings [31,34,35]. As Wright [36] (p. 348) notes, 'informal gendered practices have particular power to significantly affect the day-to-day experience of women who are in a minority in highly gender-imbalanced work settings'.

This study uses career capital as a theoretical framework to explore how the Middle Eastern context affects women expatriates' careers. Career capital encompasses knowingwhy, knowing-how and knowing-whom competencies $[37,38]$ that intersect identity, career choice and professional networks. In the global mobility literature, career capital and learning opportunities have been associated as a benefit of international assignments [21,39,40]. Rodriguez and Scurry [41] (p. 204) note that self-initiated expatiates (SIEs), those who relocate of their own volition, 'develop career capital in an ad hoc fashion rather than as a result of strategically planning and seeking to develop their careers and increase their employability'. Arguably, regardless of the form of global mobility, exposure to work in an international setting can be beneficial to an individual's career capital.

Berry and Bell [42] (p. 21) suggest that 'aside from their sex, women expatriates are similar in socioeconomic terms to male expatriates'. However, societal expectations, such as pressure on women to prioritise family over career, coupled with a lack of female role models [30] hamper women's career advancement in the Middle East. In the GCC region 'the social and working lives of women are structurally organised around marriage and motherhood as mechanisms to regulate gender roles for both men and women' [35] (p. 394). There is no enforced legislative equality framework in the GCC, and women are subject to lower pay and stricter recruitment and selection criteria than their male counterparts [43]. This deficit can result in characteristics that are protected in the home country, for example, sex under the UK Equality Act 2010, becoming hidden inequalities in 
the host country [44]. As Sidani, Konrad and Karam [45] (p. 285) state it is 'the perceived importance of the impact of patriarchal family structures, the explicit favouring of males over females, and the assignment of women to nurturing roles within the private sphere of the family as the major limiting factors' to women's careers, more so than the absence of a legislative framework. However, Michailova and Hutchings [46] argue that women pursue careers in developing countries which lack the equality frameworks of their home nations because they perceive greater career advancement opportunities facilitated through international experience which is shown to increase career capital [47]. Furthermore, women in dual-career relationships may experience reduced financial remuneration in the form of allowances as their spouse receives the 'family benefits' (e.g., accommodation allowances), resulting in women's international work being devalued [2].

This study adopts a synergistic approach to extend our understanding of the experiences of DCCs by exploring how the GCC as a contextual setting affects the career coordination strategies of expatriate women.

\section{Methods}

The focus of this study was to explore how contextual features of the GCC affect the careers of women in DCCs. Grounded in an interpretivist epistemology, an inductive qualitative research approach was adopted, which allowed deep and rich insight into the research participants' experiences to emerge. This approach elaborated on existing career coordination strategies theory [5] to address a gap in the existing literature by presenting empirical research.

\subsection{Sample}

A combination of purposive and snowball sampling approaches was adopted to identify and invite suitable participants to take part in the research to facilitate the research aims being achieved [48]. To be eligible for participation, participants needed to be part of a DCC and working, or recently working, as an expatriate in the GCC. Potential participants were initially identified within the author's professional and personal networks. Following the interview, referrals for further potential participants were also requested. This sampling approach was deemed appropriate as the contextual setting can make access to participants challenging [49].

The in-depth interviews used in this research were drawn from a larger qualitative study addressing the experiences of expatriate women in the Middle East. A breakdown of the demographic details of the research participants used in this study is shown in Table 1.

Table 1. Participant details.

\begin{tabular}{cccccccccc}
\hline Code & Nationality & Age & Children & Industry & Role/Seniority & $\begin{array}{c}\text { Expatriate } \\
\text { Status }\end{array}$ & $\begin{array}{c}\text { Years } \\
\text { in GCC }\end{array}$ & $\begin{array}{c}\text { Career Coordination } \\
\text { Strategy }\end{array}$ \\
\hline P1 & British & $41-50$ & 2 & Education & Professional & SIE & 4 & Egalitarian \\
\hline P2 & British & $31-40$ & 1 & Education & Administrative & SIE & 8 & Hierarchical \\
\hline P3 & American & $41-50$ & 1 & Aviation & Executive & SIE & 9 & Egalitarian \\
\hline P4 & Romanian & $31-40$ & 2 & Engineering & Senior Manager & AE & 4 & Hierarchical \\
\hline P5 & British & $31-40$ & 2 & Engineering & Management & SIE & 5 & Egalitarian \\
\hline P6 & British & $31-40$ & 0 & Aviation & Management & SIE & 6 & Hierarchical \\
\hline P7 & American & $41-50$ & 0 & Education & Management & SIE & 5 & Hierarchical \\
\hline P8 & American & $41-50$ & 1 & Healthcare & Department Head & SIE & 7 & Loose \\
\hline P9 & British & $31-40$ & 0 & Aviation & Management & SIE & 4 & Loose \\
\hline & & & & & 15 & &
\end{tabular}




\subsection{Interview Guide and Procedure}

The interview guide was developed based on the theoretical framework which underpins the study and comprises five key themes to guide open-ended questions: participants' background, expatriation destination, adjustment, family and career coordination strategy. An example of the interview guide is shown in Table 2. The interviews were conducted either face-to-face or using a voice-over-internet protocol when meeting in person was not feasible. The interviews typically lasted about an hour. The interviews were digitally recorded and later transcribed. All participants were offered the opportunity to review the transcripts before the analysis commenced. Ethical guidelines were observed throughout, participants maintained the right to withdraw at any time and any identifying personal data were anonymised.

Table 2. Interview guide.

\begin{tabular}{|c|c|}
\hline Topic & Example Question Asked \\
\hline Professional background & $\begin{array}{l}\text { Please tell me about your professional background and any previous overseas experience. } \\
\text { What were your reasons for relocating internationally? }\end{array}$ \\
\hline Destination & $\begin{array}{l}\text { What were your initial perceptions of [host country]? Where there any appealing/deterring factors? } \\
\text { What were your aspirations for the international experience? }\end{array}$ \\
\hline Adjustment & $\begin{array}{c}\text { Can you tell me about your mobilisation experience? } \\
\text { What initial cultural differences did you experience? } \\
\text { What was the role of internal/external networks during your adjustment? } \\
\text { What challenges did you face? } \\
\text { What support did you receive? }\end{array}$ \\
\hline Family & $\begin{array}{c}\text { Who relocated with you? } \\
\text { What opportunities did the international experience provide for your family? } \\
\text { What challenges did your family face? } \\
\text { How did you manage your work-life balance? }\end{array}$ \\
\hline Career coordination strategy & $\begin{array}{c}\text { How did you prioritise your career? } \\
\text { How did you access career opportunities? } \\
\text { Did you encounter any career barriers? } \\
\text { Have you ever had to compromise on your career plan? } \\
\text { How has your career plan changed? }\end{array}$ \\
\hline
\end{tabular}

\subsection{Data Analysis}

The interview data were organised using qualitative analysis software (NVIVO version 12) and followed the three-stage data reduction method of Gioia, Corley and Hamilton [50]. In the first stage, the transcripts were 'open coded' drawing on King's [51] template analysis approach to develop a priori codes informed by the existing literature and emergent codes from the interview transcripts. Examples of a priori codes include 'egalitarian intentions' (see [5]), 'challenges finding work' [35] and 'visa restrictions' (see [52]). The a priori codes were used to develop an initial coding template. Then, following an iterative process [53] of reading the existing literature and analysing the interview data, a final template was produced. Figure 1 provides an example of the first order codes. 
[My husband's] job pays a little bit better than mine, but not so much. We were at the point Egalitarian where it would have been either one of us. The thing was, I was working for a national company intentions and he was working for a company that was going international. So we were pretty sure that it was going to be his job that would take us somewhere.

It took me about nine months to find the job at [employer], and it was hell. I am not a stay at home person; I don't like to be unemployed. And of course you don't know, if somebody had told me it's going to take you nine months and then you'll have a great job and you'll be fine, then piece of cake. But when you don't know and you're starting to think oh my god, am I going to be here for two years without a job, I'm going to kill myself. Then you start, you know, panicking.

And so I would have been perfectly happy to get, you know, some part-time job ... just to fill the time a bit, meet some people. You can't do that here. They would have laughed me out of the store. So that was surprising, and super annoying to me.

And he, you know, now he makes way more money than I do, he used to make a little more money than I do, now he makes way more, so it's kind of like, okay.

Figure 1. Example first order codes.

The second stage involved organising the first order codes into thematic categories to 'describe and explain the phenomena' [50] (p. 21). During this process, Defillippi and Arthur's [37] notion of career capital was used to consider how the women expatriate's careers were affected.

In the final stage, aggregate theoretical dimensions were distilled which focused on how the research context impacted the participants' career capital and whether this impact resulted in a change to their coordinated career strategy. Figure 2 illustrates an example of the progression from data coding to the theoretical dimensions that emerged in this study.

\section{First order codes \\ Thematic categories \\ Theoretical dimensions}

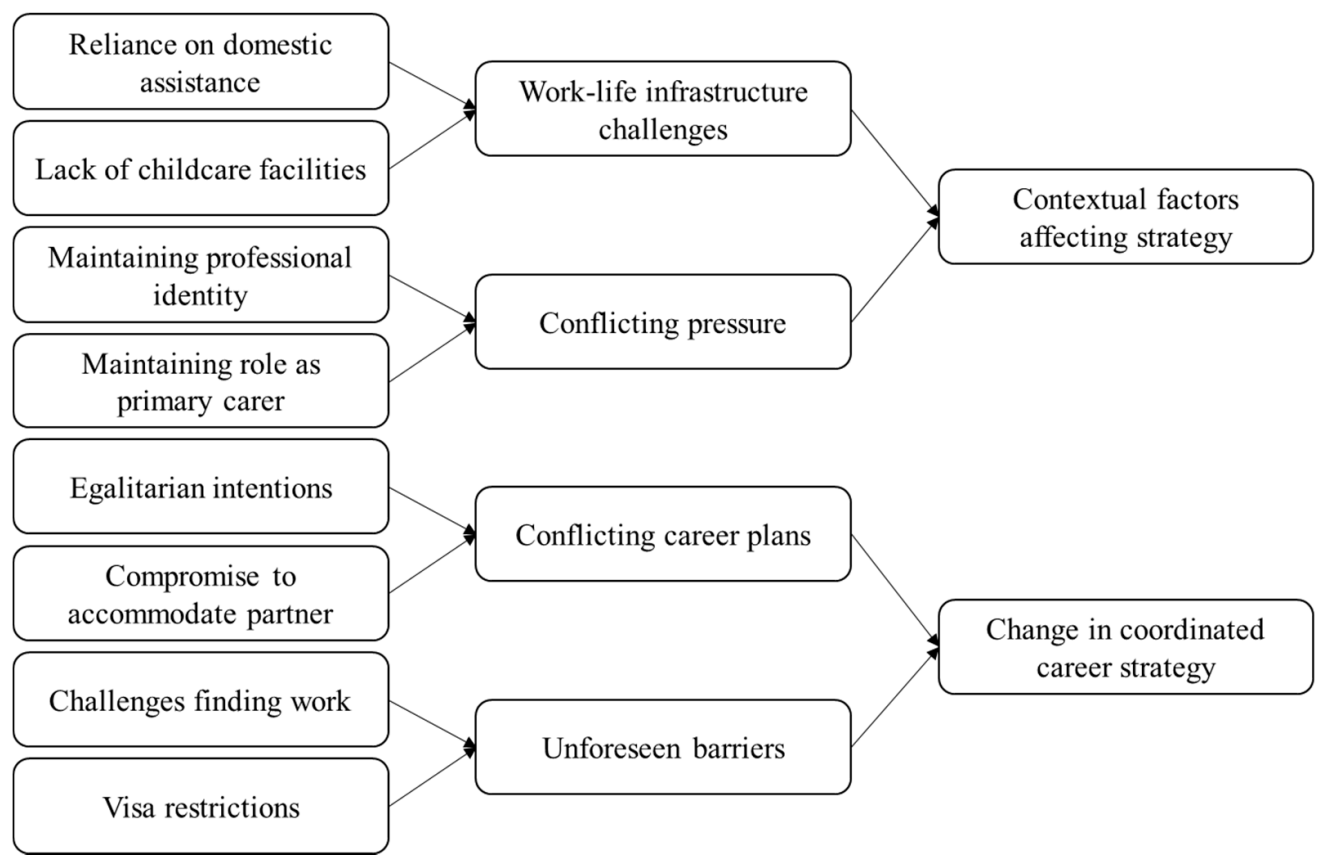

Figure 2. Example data structure.

\section{Results}

\subsection{Conflicting Career Plans}

The different ways in which participants had sacrificed their careers emerged as a theme from the research. P3, following an egalitarian career coordination strategy, reflects 
on previously resigning from a job to reduce the time that she spent away from her husband due to working in different GCC cities.

'I think yes if I had said I sacrificed anything it would be when I resigned from [my previous employer] and worked in Kuwait. It was a pretty big step back, but again it was better that we were together and that we were both in Kuwait rather than travelling every week. So it was for the right reasons.'

Contextually, P3 had to be the one to resign and move to Kuwait as her husband could sponsor her while she looked for a new role. As women are usually unable to sponsor their husbands in the GCC, the reverse scenario would not have been possible. The nature of the context forces men's careers to be prioritised over women's, despite their initial egalitarian coordination intentions.

P7 and her husband relocated to the UAE from the US. Initially, neither partner was following the other, indicating an egalitarian coordination career strategy as both partners were eager to pursue international careers; however, an opportunity for $\mathrm{P7}^{\prime} \mathrm{s}$ husband arose first. While she intended to relocate, she did so without having secured employment and thus sacrificed her established career in the US. P7's narrative shows how their initial career strategy did not go according to plan.

'[My husband's] job paid a little bit better than mine, but not much. We were at the point where it would have been either one of us. I left a really, really good job, that in the midst of my darkest days I regretted horribly. It took me about nine months to find the job at AirCo, and it was hell. I am not a stay-at-home person; I don't like to be unemployed.'

P7 faced challenges finding employment upon arrival in the UAE which she did not expect, highlighting the challenge of navigating access to careers in different contextual settings. In RP7's continuing narrative, she explains the difficulty she faced in finding employment.

'It took a serious toll on my confidence, and my ego. The problem was I was applying primarily for jobs that you saw on the web, because I didn't have a network, I didn't have anything established. I ended up getting my job because I started playing mah-jong, I was talking about my job search and [my friend said her] husband works at AirCo, and voila, two months later I have a job.'

P7's story highlights the importance of networks; networks are a critical contextual feature of the GCC. Due to sociocultural practices and the gendered nature of the environment, the only network that P7 could access was with other women who did not work. Keira, who followed a hierarchical career coordination strategy, experienced similar problems in applying for jobs in the GCC.

'Applying was just disastrous. I think I applied for a million jobs and didn't hear anything. No confirmation they'd received anything, and it was quite soul destroying. Or you'd find an advert that seemed alright, and then it was like, but you need to be on your husband's visa.'

At the time of relocating to the GCC, Keira moved with her partner, but they were not married. They had agreed that they would move to benefit his career but had not realised the implications of being unmarried and the challenge that presented to Keira as she could not secure a work visa in her own right without a job. As they were not married, her partner was unable to sponsor her resulting in her having to leave and re-enter the country frequently on a visitor's visa. Many organisations in the UAE prefer female job applicants, particularly for clerical roles, to be sponsored by their husbands as they can save on the associated fees and other compulsory provisions, such as medical insurance, which would, instead, be provided by the husband's employer.

\subsection{Work-Life Infrastructure Challenge}

While in the UAE, P7 and her husband had another opportunity to relocate to the UK, again following her husband's career. 
'And Bristol was, for [my husband], a better career move. Now he makes way more money than I do; he used to make a little more money than I do, now he makes way more.'

The trajectory of P7's career throughout her international experience has shown how the sociocultural context of working in the GCC has reshaped her and her husband's initial egalitarian coordinated career strategy into a hierarchical one. Although both partners were eager to pursue international careers, contextual features made it difficult for P7 to access a career in the UAE and have led to her career lagging.

Keira and her partner married; her continued narrative reveals that she felt overly reliant on his network, and to continue her career, she drastically compromised on her career expectations.

'When you've only really got your husband's work friends as friends, you don't have your own life really ... I think at that point it was just like, I will take any money, I don't care, I just need to do something.'

Although, in Keira's case, it was the intention that the international move was to benefit her husband's career, following a hierarchical coordinated career strategy, the inability for her to access work and accept lower-level work affected her career.

P5 and her husband worked for the same organisation in the UK and relocated to Qatar with their two young children. P5 and her husband had both discussed overseas employment opportunities alluding to an egalitarian coordinated career strategy as neither partner's career was prioritised over the other. P5 discussed the challenges she faced while continuing to pursue a career overseas and remaining the primary caregiver for children. To cope with the double burden of managing her career and being the primary caregiver, she eventually managed to reduce her working hours, a very rare occurrence in the GCC. Subsequently, she did not feel that she benefitted from the international experience to the same extent as her husband as her narrative reveals in the following quote.

'[My husband] is going to be quite lucky, he's found himself a role in the UK business. He's going to be working in a team where there's international travel and the team that he worked with to establish the project in Qatar five years ago. I haven't; it's difficult knowing where to go'.

$\mathrm{P} 5^{\prime} \mathrm{s}$ husband has secured a role back in the UK with their existing employer which draws on his international experience. In contrast, however, P5 is not clear about her next career step nor how the international experience has benefitted her longer-term career.

\subsection{Unforeseen Barriers}

P8 and her husband follow a loose coordinated career strategy in which partners take career decisions independently.

'They talk about the glass ceiling; they talk about women not being equal in the workforce.

I've been a senior director now, in my last job in California ... I'd never felt that being female caused me any disadvantages ... I think... I fall into the trap that women here do, and I am less aggressive and assertive as my male counterparts are.'

Despite having progressed to a senior level in her profession, $\mathrm{P}^{\prime}$ 's narrative alludes to the contextual setting influencing the way she interacts in the workplace as she felt the need to modify her behaviour to align with the ways that women are perceived in the workplace in the GCC. In changing her behaviour, she suggests that she is reinforcing the glass ceiling as she has not previously felt that being female has disadvantaged her in the workplace. As P8 followed a loose career strategy, the barriers she faces could be argued to be those that any woman working in the GCC would face and not directly linked to a coordinated career strategy.

The following excerpt from P3's narrative points to the work environment being maledominated and how this is presenting a perceived barrier to her continuing career progression.

'You don't see a lot of women at the executive level in many of the companies across the

UAE. [My husband] wants to progress his career further, and I don't know if I'll get 
much further in [my current employer]. I just think that there's a little bit of a glass ceiling. A lot of people in the Middle East who work are men, so therefore by default there ends up being boys' clubs, whether you like it or not. My male colleague is more comfortable talking to another male colleague rather than talking to me.'

Like P8, P3 refers to the 'glass ceiling' that she is facing which is amplified by the lack of female role models in the region, but she intends to remain overseas to support her husband's career progression. This intention suggests a change in coordinated career strategy away from egalitarian strategy to a hierarchal strategy where her husband's career is favoured over hers.

P1 worked as a teacher and her husband as a human resource professional. They applied for vacancies in the UAE in parallel and both secured employment opportunities; their coordinated career strategy was egalitarian insofar as neither partner's career took priority, and it was her role that was the trigger to relocate. They relocated with their two young children. P1 reflects on the challenges of caring for children while maintaining a career and the subsequent reliance on domestic assistance.

'If you have children you have to have a maid essentially because they don't really have any childcare, particularly before school and after school. It's very difficult to have two people in a family with young children who are both careers-driven, so one of you does have to step back a bit in order to maintain family unity. I never wanted to devolve my responsibility as a mother to someone else.'

Traditionally, women are expected to prioritise care for their families over their careers. As women's participation in the labour market increases, this has resulted in a growing reliance on domestic workers [54]. One explanation is the limited frameworks, such as flexible work arrangements, that enable women, and arguably men, to take care of dependents while concurrently pursuing a career. The lack of such infrastructure to support DCCs in the GCC presented a barrier to P1's career progression as she felt that she had to take a step back to continue being the primary caregiver for her children, despite the availability of domestic assistance. P1 had secured employment in her own right when relocating to the GCC, but she acknowledges that her career did not progress, nor deteriorate, while overseas. In her continuing narrative, she notes that if she had remained overseas for a longer period, however, there was a risk that she would not have been able to secure employment following her repatriation to the UK.

'I didn't really develop my career in any way. I was head of department in the UK and then I took a job out in the Middle East as just a plain main pay scale teacher. I didn't progress my career, and by the end of the experience I hadn't gone backwards either, so I remained at the same place. And in teaching, your experience in the British education system is actually more important than experience abroad, so if I'd have stayed out much longer than four years then I may not have been able to get a job when I got back into the UK.'

Although the domestic assistance allowed P1 to continue working, her narrative exposes the difficulty of both partners remaining career-driven. P1 later returned to the UK; her and her husband's career strategy became hierarchical in favour of her husband's career.

\subsection{Prioritising Women's Careers}

An exception of the research participants was $\mathrm{P} 4$; in her case, she and her husband pursued a hierarchical coordinated career strategy in which her career was prioritised. The following excerpt shows how P4 feels the international experience has benefitted her career:

It's given me what I want. I wanted to develop this networking amongst different departments and being in the project management office is clearly working with everybody. I had a very significant involvement in the commercial and financial management of the work that we are doing here, which is something, a box that I needed to tick in my experience, which is great. 
While P4 is part of a DCC, her career took priority in a hierarchal strategy which may explain how her experience contrasted the other cases.

\section{Discussion}

Existing studies have shown that there is a rise in the number of DCCs and how partners in a DCC adopt different coordinated career strategies [5]. However, limited consideration has been given to how host country sociocultural features affect DCC coordinated career strategies. This article does not seek to generalise across contexts; however, insights can be drawn within a specific context that may be applicable elsewhere. This study has highlighted that the Middle Eastern context may arguably force a DCC to adopt a hierarchal career strategy, prioritising the husband's career. Furthermore, this study contributes to existing knowledge by suggesting that not only are women's career hampered while based in the GCC, but the contextual setting could have a long-term adverse effect on women's career capital. Thus, this article contributes to the existing debate on DCC s by arguing that contextual features force a 'tipping point', creating a lag in women's careers that prohibits their careers from being prioritised during future overseas stints and negatively impacting their career capital. Interestingly, although the participants in this study were 'elite' expatriates, the social division of gender resulted in 'downward occupational mobility in the labour market hierarchy' [55] (p. 392).

As the findings indicate, women's knowing-why career capital is potentially impacted as their careers are deprioritised forcing their identity into that of trailing spouse despite previously having their own career identity. This finding offers an alternative perspective to existing literature [13], which argued that joint role salience was a more important factor affecting the willingness to relocate internationally. The change of identity to trailing spouse is amplified in the GCC context as women are often reliant on their husband's visa sponsorship until they find work. While networks have been acknowledged as crucial to forging career capital [21], this study has highlighted that sociocultural features can inhibit network access and subsequently work opportunities which can damage women's confidence.

Reflective of earlier work [12], participants knowing-how career capital was hindered as they found themselves in situations where they had to compromise on career choices either to prioritise family over career or to accept a low-level role to avoid unemployment. Unlike earlier studies [22], however, the negative impact on women's knowing-how career capital extended beyond the time spent in the GCC as upon repatriation, or further overseas opportunities, their husbands often had a clearer career direction benefiting from the time in the GCC. In contrast, the careers of women in DCCs had lagged or no career capital had been gained, thus impacting their longer-term career prospects.

The findings indicate that the contextual setting of the GCC could negatively impact women's knowing-who career capital as the patriarchal environment presents barriers to women trying to access male-dominated networks. These barriers often hindered women's access to employment opportunities and career progression, reinforcing their husband's careers as being prioritised over their own.

The participants gave examples of the challenges and personal conflict that they have faced trying to manage their international careers and family commitments, reflecting existing studies [20,24]; this is more prevalent for participants who have children. In their stories, the participants did not imply that these conflicts were also being experienced by their partners. Thus, despite coordinated career strategies and full-time employment, the female partners still maintained responsibility as the primary caregiver for dependents and subsequently experienced career lag.

In $\mathrm{P} 1^{\prime}$ s case, even in her position of being a privileged Western expatriate with access to domestic assistance which allowed her to continue working, she was unable to maintain an egalitarian career strategy with her partner. P1 suggested that it was the responsibility for children that prevented her career from progressing; however, P7's story shows that the patriarchal setting had a negative effect. Gender segregation as a sociocultural feature impacted P7 and led her to struggle to find employment. Although part of a DCC with an 
egalitarian coordinated career strategy, the inability to secure employment led to her career lagging despite leaving a very good job in her home country. If she had remained in her home country, her career may not have lagged.

\section{Conclusions}

This study aimed to understand how the career capital of expatriate women is affected by working in the Middle East as part of a DCC. The findings from this study suggest that contextual features can influence coordinated career strategies. Women in DCC who follow a loose coordinated career strategy appear to encounter the same barriers as other women who work in the region who are not part of a DCC, as they manage their careers independently of their husbands. For the women who were part of a DCC with a hierarchical career strategy in which their husbands' careers were prioritised, they may not have expected to gain career capital but simultaneously experienced career lag due to the dependence on their husband's careers for their ability to work. This is an important contextual feature of the GCC which has an impact on coordinated career strategies. The women who initially followed an egalitarian coordinated career strategy, in which both partners' careers are given equal priority, appear to be those whose careers are most hampered by the contextual setting, often resulting in a change to a hierarchical coordinated strategy, favouring their husband's career.

Interestingly, only one participant reflected on how the expatriate experience has enhanced her career capital, which the existing literature suggests can be expected from a foreign sojourn [47]. Caligiuri and Bonache [1] suggest that the 'trailing' partner is often more affected during international relocation when they are unable to continue their career; this study advances our understanding by arguing that even in DCCs with a strategy that neither partner's career takes priority, contextual features can hinder the female partner's career. This argument leads to the consideration that only when the DCC intends to prioritise the female partner's career can the sociocultural barriers that are more prevalent for women be overcome. The existing literature has established that sacrifices need to be made to balance having a family and a career [1]. This research revealed, however, that even in DCCs where the career coordination strategy is egalitarian, contextual features of the host country setting result in the sacrifice falling on expatriate women. Thus, this article contributes to knowledge by addressing the research question and argues that sociocultural features such as gendered segregation and societal expectations of women can result in female expatriates' career lagging, despite coordinated career strategies.

\subsection{Practical Implications}

The importance of organisations providing support for expatriates' spouses' careers has already been noted [1], and the findings from this study suggest that such support may be of even greater importance for partners in DCCs. To avoid female expatriates' professionalism being overshadowed by the dual-career status [2], policies and practices are needed to aid expatriates in settling their families [20]. These policies and practices must be proactive in positioning support as being available to both male and female expatriates to avoid primary caregiver responsibilities defaulting to female partners of DCCs.

Individual expatriates in DCCs should challenge and reflect on their coordinated career strategies in the context of the overseas destination to which they are relocating. Thus, the destination may influence the decision to relocate [52]. It may be necessary to adjust according to the sociocultural features of the environment rather than assuming that the same access and features apply as in their home country. Prior reflection and discussion should help to prevent either partner's career from lagging, and working together will help to ensure that both partners can maximise the career capital from the international experience. 


\subsection{Limitations and Future Research}

It was not the intention of this study to provide generalisations; rather, the focus was to investigate the subjective lived experiences of the participants. However, it is important to acknowledge that the sample size used in this study was very small. A further limitation of this study is that stories only represent one side of a DCC, as Shortland and Perkins [2] state; however, it is important to expose women expatriates' stories due to their underrepresentation. Some participants in this study did not allude to their husband's career outcomes, only the career focus; it should not be assumed that their husband's career outcomes were positive. Research undertaken with both partners within a DCC would provide more insight. Thus, future research could seek to understand the perspectives of both partners and if the career success of one partner is at the cost of the career detriment or sacrifice of the other. In consideration of a 'tipping point', future research could seek to determine whether women's career capital can be recovered in the future and whether DCCs can 'take turns' prioritising their careers following a tipping point forced by a contextual setting.

The GCC has provided an interesting geographical context due to the region's reliance on a foreign workforce and its unique socio-political and cultural features. It would be interesting to explore how different contextual settings influence the coordinated career strategies of DCCs.

Funding: This research received no external funding.

Institutional Review Board Statement: The study approved by the Ethics Committee of Nottingham Business School, Nottingham Trent.

Informed Consent Statement: Informed consent was obtained from all subjects involved in the study.

Data Availability Statement: Not applicable.

Acknowledgments: The author would like to thank Nadia Kougiannou for her support and feedback during the preparation of this article.

Conflicts of Interest: The author declares no conflict of interest.

\section{References}

1. Caligiuri, P.; Bonache, J. Evolving and enduring challenges in global mobility. J. World Bus. 2016, 51, 127-141. [CrossRef]

2. Shortland, S.; Perkins, S.J. Long-term assignment reward (dis)satisfaction outcomes: Hearing women's voices. J. Glob. Mobil. 2016, 4, 225-250. [CrossRef]

3. Varma, A.; Russell, L. Women and expatriate assignments: Exploring the role of perceived organizational support. Empl. Relat. 2016, 38, 200-223. [CrossRef]

4. Gripenberg, P.; Niemistö, C.; Alapeteri, C. Ask us equally if we want to go. J. Glob. Mobil. 2013, 1, 287-311. [CrossRef]

5. Känsälä, M.; Mäkelä, L.; Suutari, V. Career coordination strategies among dual career expatriate couples. Int. J. Hum. Resour. Manag. 2014, 26, 2187-2210. [CrossRef]

6. GCC Statistical Centre. Labour Force (15 Year and above) by Nationality and Gender in GCC Countries, 2011-2015. Available online: https:/ / gccstat.org/en (accessed on 22 June 2018).

7. Baruch, Y.; Forstenlechner, I. Global careers in the Arabian Gulf: Understanding motives for self-initiated expatriation of the highly skilled, globally mobile professionals. Career Dev. Int. 2017, 22, 3-22. [CrossRef]

8. Kemp, L.J.; Rickett, B. The lived experiences of foreign women: Influences on their international working lives. Gend. Work Organ. 2018, 25, 343-360. [CrossRef]

9. Andresen, M.; Bergdolt, F.; Margenfeld, J.; Dickmann, M. Addressing international mobility confusion—developing definitions and differentiations for self-initiated and assigned expatriates as well as migrants. Int. J. Hum. Resour. Manag. 2014, 25, $2295-2318$. [CrossRef]

10. Haak-Saheem, W.; Brewster, C. 'Hidden' expatriates: International mobility in the United Arab Emirates as a challenge to current understanding of expatriation. Hum. Resour. Manag. J. 2017, 27, 423-439. [CrossRef]

11. Roos, H. In the rhythm of the global market: Female expatriates and mobile careers: A case study of Indian ICT professionals on the move. Gend. Work Organ. 2013, 20, 147-157. [CrossRef]

12. Miano, P.; Salerno, A.; Merenda, A.; Ciulla, A. Whose Turn Is It? Problems of Reconciling Family and Work in Dual-Career Couples. Int. J. Humanit. Soc. Stud. 2015, 3, 147-153. 
13. van der Velde, M.E.G.; Jansen, P.G.W.; Bal, P.M.; van Erp, K.J. Dual-earner couples' willingness to relocate abroad: The reciprocal influence of both partners' career role salience and partner role salience. Eur. J. Work Organ. Psychol. 2016, 26, 195-207. [CrossRef]

14. Tharenou, P. Self-initiated expatriates: An alternative to company-assigned expatriates? J. Glob. Mobil. 2013, 1, 336-356. [CrossRef]

15. Mayerhofer, H.; Hartmann, L.C.; Michelitsch-Riedl, G.; Kollinger, I. Flexpatriate assignments: A neglected issue in global staffing. Int. J. Hum. Resour. Manag. 2004, 15, 1371-1389. [CrossRef]

16. Baluku, M.M.; Löser, D.; Otto, K.; Schummer, S.E. Career mobility in young professionals: How a protean career personality and attitude shapes international mobility and entrepreneurial intentions. J. Glob. Mobil. 2018, 16, 102-122. [CrossRef]

17. Suutari, V.; Brewster, C.; Mäkelä, L.; Dickmann, M.; Tornikoski, C. The effect of international work experience on the career success of expatriates: A comparison of assigned and self-initiated expatriates. Hum. Resour. Manag. 2018, 57, 37-54. [CrossRef]

18. Harvey, M.; Novicevic, M.; Breland, J.W. Global dual-career exploration and the role of hope and curiosity during the process. J. Manag. Psychol. 2009, 24, 178-197. [CrossRef]

19. Slobodin, O. The Voice of Trailing Women in the Decision to Relocate: Is It Really a Choice? In People's Movements in the 21st Century-Risks, Challenges and Benefits; IntechOpen: London, UK, 2017; pp. 261-273. Available online: https: / / www.intechopen.com/books / people-s-movements-in-the-21st-century-risks-challenges-and-benefits / the-voice-oftrailing-women-in-the-decision-to-relocate-is-it-really-a-choice- (accessed on 18 June 2021).

20. Mäkelä, L.; Suutari, V.; Mayerhofer, H. Lives of female expatriates: Work-life balance concerns. Gend. Manag. Int. J. 2011, 26, 256-274. [CrossRef]

21. Kirk, S. Career capital in global Kaleidoscope Careers: The role of HRM. Int. J. Hum. Resour. Manag. 2016, 27, 681-697. [CrossRef]

22. Kierner, A.; Suutari, V. Repatriation of international dual-career couples. Thunderbird Int. Bus. Rev. 2017, 60, 885-895. [CrossRef]

23. Laroche, L.; Bing, C.M. Negotiating Expatriate Packages. Available online: http://www.itapintl.com/index.php/about-us/ articles/negotiating-expatriate-packages (accessed on 10 March 2017).

24. Fischlmayr, I.C.; Puchmüller, K.M. Married, mom and manager-How can this be combined with an international career? Int. J. Hum. Resour. Manag. 2016, 27, 744-765. [CrossRef]

25. Shortland, S. The 'expat factor': The influence of working time on women's decisions to undertake international assignments in the oil and gas industry. Int. J. Hum. Resour. Manag. 2015, 26, 1452-1473. [CrossRef]

26. Sidani, Y.M.; Al Ariss, A. Institutional and corporate drivers of global talent management: Evidence from the Arab Gulf region. J. World Bus. 2014, 49, 215-224. [CrossRef]

27. Herod, A.; Rainnie, A.; Mcgrath-Champ, S. Working space: Why incorporating the geographical is central to theorizing work and employment practices. Work Employ. Soc. 2007, 21, 247-264. [CrossRef]

28. Metcalfe, B.D.; Rees, C.J. Gender, globalization and organization: Exploring power, relations and intersections. Equal. Divers. Incl. Int. J. 2010, 29, 5-22. [CrossRef]

29. Hennekam, S.; Tahssain-Gay, L.; Syed, J. Contextualising diversity management in the Middle East and North Africa: A relational perspective. Hum. Resour. Manag. J. 2017, 27, 459-476. [CrossRef]

30. Metcalfe, B.D. Gender and human resource management in the Middle East. Int. J. Hum. Resour. Manag. 2007, 18, 54-74. [CrossRef]

31. Hutchings, K.; Lirio, P.; Metcalfe, B.D. Gender, globalisation and development: A re-evaluation of the nature of women's global work. Int. J. Hum. Resour. Manag. 2012, 23, 1763-1787. [CrossRef]

32. Bardot, S. Background on Work Life in the United Arab Emirates and Other Gulf Countries (Gulf Cooperation Council). Compens. Benefits Rev. 2013, 45, 21-25. [CrossRef]

33. De Bel-Air, F. Demography, Migration, and the Labour Market in the UAE. Available online: http://cadmus.eui.eu/bitstream/ handle/1814/36375/GLMM_ExpNote_07_2015.pdf?sequence=1\&isAllowed=y (accessed on 21 May 2021).

34. Syed, J.; Ali, F.; Hennekam, S. Gender equality in employment in Saudi Arabia: A relational perspective. Career Dev. Int. 2018, 23, 163-177. [CrossRef]

35. Rodriguez, J.K.; Ridgway, M. Contextualizing privilege and disadvantage: Lessons from women expatriates in the Middle East. Organization 2019, 26, 391-409. [CrossRef]

36. Wright, T. Women's Experience of Workplace Interactions in Male-Dominated Work: The Intersections of Gender, Sexuality and Occupational Group. Gend. Work Organ. 2016, 23, 348-362. [CrossRef]

37. Arthur, M.B.; Defillippi, R. The boundaryless career: A competency-based perspective. J. Organ. Behav. 1994, 15, 307-324. [CrossRef]

38. Brown, C.; Hooley, T.; Wond, T. Building career capital: Developing business leaders' career mobility. Career Dev. Int. 2020, 25, 445-459. [CrossRef]

39. Dickmann, M.; Doherty, N. Exploring the career capital impact of international assignments within distinct organizational contexts. Br. J. Manag. 2008, 19, 145-161. [CrossRef]

40. Suutari, V.; Mäkelä, K. The career capital of managers with global careers. J. Manag. Psychol. 2007, 22, 628-648. [CrossRef]

41. Rodriguez, J.K.; Scurry, T. Career capital development of self-initiated expatriates in Qatar: Cosmopolitan globetrotters, experts and outsiders. Int. J. Hum. Resour. Manag. 2014, 25, 190-211. [CrossRef]

42. Berry, D.P.; Bell, M.P. “Expatriates”: Gender, race and class distinctions in international management. Gend. Work Organ. 2012, 19, 10-28. [CrossRef] 
43. Al-Waqfi, M.A.; Al-Faki, I.A. Gender-based differences in employment conditions of local and expatriate workers in the GCC context: Empirical evidence from the United Arab Emirates. Int. J. Manpow. 2015, 36, 397-415. [CrossRef]

44. Ridgway, M. Hidden Inequalities of the Expatriate Workforce. In Hidden Inequalities in the Workplace; Caven, V., Nachimas, S., Eds.; Palgrave Macmillan: Cham, Switzerland, 2017; pp. 303-330.

45. Sidani, Y.M.; Konrad, A.; Karam, C.M. From female leadership advantage to female leadership deficit: A developing country perspective. Career Dev. Int. 2015, 20, 273-292. [CrossRef]

46. Michailova, S.; Hutchings, K. Critiquing the marginalised place of research on women within international business. Crit. Perspect. Int. Bus. 2016, 12, 348-368. [CrossRef]

47. Dickmann, M.; Suutari, V.; Brewster, C.; Mäkelä, L.; Tanskanen, J.; Tornikoski, C. The career competencies of self-initiated and assigned expatriates: Assessing the development of career capital over time. Int. J. Hum. Resour. Manag. 2018, 29, $2353-2371$. [CrossRef]

48. Saunders, M.N.K. Choosing Research Participants. In Qualitative Organizational Research; Symon, G., Cassell, C., Eds.; Sage Publications Ltd.: London, UK, 2016; pp. 35-52.

49. Ridgway, M.; Robson, F. Intersectional challenges of conducting qualitative research in the Middle East. In Field Guide to Intercultural Research; Guttormsen, D., Lauring, J., Chapman, M., Eds.; Edward Elgar: Cheltenham, UK, 2021 ; pp. $296-310$.

50. Gioia, D.A.; Corley, K.G.; Hamilton, A.L. Seeking Qualitative Rigor in Inductive Research: Notes on the Gioia Methodology. Organ. Res. Methods 2012, 16, 15-31. [CrossRef]

51. King, N. Using templates in the thematic analysis of text. In Essential Guide to Qualitative Methods in Organizational Research; Cassell, C., Symon, G., Eds.; SAGE Publications Ltd.: London, UK, 2004; pp. 256-270.

52. Ridgway, M.; Robson, F. Exploring the motivation and willingness of self-initiated expatriates, in the civil engineering industry, when considering employment opportunities in Qatar. Hum. Resour. Dev. Int. 2018, 21, 24-45. [CrossRef]

53. Srivastava, P.; Hopwood, N. A Practical Iterative Framework for Qualitative Data Analysis. Int. J. Qual. Methods 2009, 8, 76-84. [CrossRef]

54. Tayah, M.-J.; Assaf, H. The Future of Domestic Work in the Countries of the Gulf Cooperation Council. Available online: www.abudhabidialogue.org (accessed on 21 May 2021).

55. Ressia, S.; Strachan, G.; Bailey, J. Operationalizing Intersectionality: An Approach to Uncovering the Complexity of the Migrant Job Search in Australia. Gend. Work Organ. 2017, 24, 376-397. [CrossRef] 